\title{
Business Ecosystem \& Strategy

\section{The effect of workplace well-being and workplace incivility on turnover intention with job embeddedness as a moderating variable}

\author{
Nur Afni Khairunisa ${ }^{(a)}$ (D) Muafi Muafi ${ }^{(b)^{*}}$ \\ Crossref \\ ${ }^{(a)}$ Master of Management, Department of Management, Faculty of Business and Economics, Islamic University of Indonesia,55283, Yogyakarta, \\ Indonesia \\ ${ }^{(b)}$ Department of Management, Faculty of Business and Economic, Islamic University of Indonesia, 55283, Yogyakarta, Indonesia
}

\author{
A R T I CLE INFO \\ Article history: \\ Received 04 January 2022 \\ Received in rev. form 03 Febr. 2022 \\ Accepted 05 February 2022 \\ Keywords: \\ Turnover Intention, Workplace Well- \\ Being, Workplace Incivility, Job \\ Embeddedness \\ JEL Classification: \\ O15, M12, M21
}

\begin{abstract}
A B S T R A C T
Turnover intention is an employee's desire to move to another agency or stop working on their own volition or voluntarily from the organization where they work for certain reasons. Turnover intention behavior has a negative impact on the smooth operation of the organization, so it is necessary to study the factors that influence it and efforts to prevent it. This study aims to examine the effect of workplace well-being and workplace incivility on turnover intention, as well as to examine the role of job embeddedness in moderating the relationship between the two independent variables with the above dependent on employees of the Ministry of Agriculture vertical agency in Manokwari. This study uses a quantitative approach involving 121 respondents. Data analysis using Partial Least Square (PLS) with the help of SmartPLS 3.0 software. The results showed that; (1) workplace well-being has a negative and significant effect on turnover intention, (2) workplace incivility has a positive and significant effect on turnover intention, (3) job embeddedness significantly plays a role in moderating the relationship between workplace well-being and turnover intention, and (4) Job embeddedness plays a significant role in moderating the relationship between workplace incivility and turnover intention. To prevent turnover intention behavior in employees of the Ministry of Agriculture's vertical agency in Manokwari, it is suggested that the level of job embeddedness should always be maintained and improved for all employees of the Ministry of Agriculture's vertical agency in Manokwari.
\end{abstract}

\section{Introduction}

Human resources (HR) is one of the important factors of an organization, both government and private organizations. In essence, HR is in the form of humans who are employed in an organization as movers, thinkers and planners to achieve the goals of the organization, so that HR is the key that determines the development of the organization. An organization that has quality human resources will produce quality output for the organization. In order to create these ideal conditions, the role of good HR management (HRM) is very much needed in order to make a good contribution to the organization. With professional HRM, organizations are able to create a workforce that has a competitive advantage that will benefit the organization.

Kehoe \& Wright (2013) say that the HRM practice of an organization is reflected in the behavior and attitudes of its employees. If the behavior and attitudes of employees show positive things, it means that HRM practices are successful in carrying out their duties. However, if the HRM practice fails in carrying out its duties, various problems will arise in the HR field which can cause employees to feel uncomfortable and dissatisfied in carrying out their work so that it can lead to a desire to leave the organization or move to work elsewhere (turnover intention).

* Corresponding author. ORCID ID: 0000-0002-3926-7496

(C) 2022 by the authors. Hosting by Bussecon International Academy. Peer review under responsibility of Bussecon International Academy. http://dx.doi.org/10.36096/ijbes.v4i1.303

Citation: Khairunisa, N. A., \& Muafi, M. (2022). The effect of workplace well-being and workplace incivility on turnover intention with job embeddedness as a moderating variable. International Journal of Business Ecosystem \& Strategy (2687-2293), 4(1), 11-23. 
The negative impact of turnover intention behavior on employees is very detrimental to the organization, because it can reduce employee productivity, motivation, discipline, and morale, and can increase the rate of work accidents because employees with turnover intention behavior tend not to focus on work and do not use all their abilities to achieve good work results, causing their productivity to be low (Suyono et al., 2020). Ozer \& Gunluk (2010) also say that high turnover intention in a company will have a negative impact on the company, especially if employees have special skills and play an important role in running the organization's operations.

The occurrence of turnover intention is something that is not desired by the organization. For this reason, every organization needs to know the factors that cause the emergence of turnover intention behavior in its employees and know how to prevent it. Many factors cause employees to decide to move to another agency. One of them is internal organizational factors, as stated by Albattat $\&$ Som (2013) that the cause of turnover is due to dissatisfaction at work, salary and poor working environmental conditions. Such conditions will lead to a low level of welfare felt by employees at work. Watoni \& Suyono (2020) emphasized that workplace wellbeing really needs to be implemented within the organization along with the high demands of work, and if the workplace well-being is felt to be lacking, it will have an impact on the desire of employees to move or leave the organization where they work.

Other factors that cause turnover intention behavior in employees include high workplace incivility behavior. The incivility crisis is considered as a cultural clash, where people with different cultural backgrounds meet in one community or organization (Hendryadi $\&$ Zannati, 2018). Some examples of workplace incivility behaviors are lack of respect for co-workers, using derogatory language, making disguised threats, gossiping, ignoring co-workers' requests, or showing disrespect towards others in the workplace (Reich \& Hershcovis, 2015). Several factors that cause the emergence of turnover intention behavior in employees as described above need to be formulated properly so that turnover intention behavior in an organization can be prevented or weakened. Job embeddedness is an attachment to work that makes employees loyal and keeps working at their organization (Saoula et al., 2018). This attachment can occur when employees feel they have a match and comfort to their work, and feel that they are losing money or many will be sacrificed if they leave their jobs. This variable is expected to play a role in preventing or weakening employee turnover intentions when problems arise related to low workplace well-being and high workplace incivility felt by employees.

Voluntary turnover of employees of the Ministry of Agriculture's vertical agencies in Manokwari has occurred several times. So far, 12 civil servants have decided on voluntary turnover. For various reasons, they moved to work in a work unit within the same ministry in another area. The results of informal interviews with several employees in these vertical agencies indicate a desire to move to work following their predecessors. Observing this trend, employee turnover intention can be a serious threat to the smooth operation and development of the vertical agency. In connection with this, this study was conducted to determine and analyze the effect of workplace well-being and workplace incivility on turnover intention, as well as to study the role of job embeddedness in moderating the relationship of the independent variables studied with turnover intention in employees of the Ministry of Agriculture vertical agency in Manokwari.

\section{Literature Review}

\section{Conceptual Background and Hypothesis Development}

\section{Turnover Intention}

Employee turnover intention is an important thing that must be considered in an organization, because it has a negative impact on employee and organizational performance. According to Abelson (1987), turnover intention is the desire of employees to withdraw, which consists of thoughts of leaving the organization, the desire to find work elsewhere, and the desire to leave the organization. Mobley (2011) said that there are two factors that influence turnover intention: internal and external factors of the organization. In addition, individual factors also influence (Price, 1989). According to Hemdi \& Nasurdin (2006), employee turnover intention can be reduced by increasing employee confidence through providing employee training and development programs, implementing a fair and formal appraisal system, and providing opportunities to improve employee careers.

\section{Workplace Well-Being}

Workplace well-being is very important to be felt by employees because it has a positive influence on employee and organizational performance. According to Page (2005), workplace well-being is a sense of well-being that workers get from their work that is related to workers' general feelings about their workplace (core affect), and satisfaction with the intrinsic and extrinsic values of their work (work values). According to Danna \& Griffin (1999) workplace well-being is influenced by three factors: work settings, personality traits, and occupational stress. In addition, job demands, job control, and job resources also affect workplace well-being (Bakker \& Demerouti, 2007). Given the enormous benefits and importance of workplace well-being for employees and organizations, it is the organization's obligation to assist employees in obtaining it (Harter et al., 2002).

\section{Workplace Incivility}

Workplace incivility is a form of deviant behavior and an attitude of disrespect/respect for co-workers at work (Andersson \& Pearson, 1999; Reich \& Hershcovis, 2015). Workplace incivility behavior experienced by employees either directly or indirectly will hinder the organization's performance in achieving its goals. Based on the results of a literature search, it is known that the factors that affect 
workplace incivility can come from organizational aspects (Torkelson et al., 2016), demographic variables (Cortina et al., 2013), sources of impoliteness (Tarraf, 2012), and past experiences. against rudeness (Glomb \& Liao, 2003; Hauge et al., 2009; Torkelson et al., 2016).

\section{Job Embeddedness}

Job embeddedness is a form of employee attachment to the organization where they work. Mitchell et al. (2001) explained that this employee attachment arises due to the combined strength of several factors that can make an employee persist to keep working and can prevent leaving work at the company where he works. Yao et al. (2004) and Nostra (2011) say that the combined strength comes from the organization (on-the-job embeddedness) and the community (off-the-job embeddedness). Holtom \& Inderriden (2006) say that high levels of job embeddedness in employees are able to control dissatisfaction, while low levels of job embeddedness can cause turnover. Researchers have found a negative relationship between job embeddedness and turnover intention (Mitchell et. al., 2001; Halbesleben \& Wheeler, 2008; Takawira et al., 2014; Allen, 2006; Crossley et al., 2007). The factors that affect job embeddedness, namely age (Reitz et al., 2010), culture or race (Gong et al., 2011), gender (Tanova \& Holtom, 2008; Lev \& Koslowsky, 2012), compensation (Karatepe , 2013), self efficacy, job satisfaction, career barriers, organizational trust, organizational commitment (Awang et al., 2013), and supervisor support and employee advocacy (Shehawy et al., 2018).

\section{Effect of Workplace Well-Being on Turnover Intention}

Danna \& Griffin (1999) suggest that aspects of workplace well-being must be met by employees so that employees can work optimally. According to him, these aspects are life satisfaction (non-work satisfaction), work/job-related satisfaction, and general health. On the other hand, Page (2005) stated that the important aspects of a feeling of well-being that must be fulfilled by employees in the workplace, namely the sense of well-being that workers get from their work which is related to workers' feelings in general towards their workplace (core affect), and satisfaction with intrinsic and extrinsic values from his work (work values). Organizations that ignore these aspects of workplace well-being can lead to turnover intention behavior in their employees. It has been reported by many researchers that workplace well-being has a negative effect on employee turnover intention (Vani, 2014; Maulana, 2018; Watoni \& Suyono, 2020; Filho \& Claro, 2019; Amin \& Akbar, 2013). Based on the description above, the researcher proposes the following hypothesis:

H1: Workplace wellbeing has a negative and significant effect on turnover intention in employees of the Ministry of Agriculture's vertical agency in Manokwari.

\section{Effect of Workplace Incivility on Turnover Intention}

Workplace incivility is low-intensity deviant behavior with ambiguous intent to harm/hurt others, violates norms of mutual respect and courtesy in the workplace, is characterized by rudeness and shows a lack of concern or neglect of others (Andersson \& Pearson, 1999). This situation causes cooperation and motivation among employees to be hampered (Pearson et al., 2000). Researchers have found that workplace incivility is positively related to turnover intention, both in various industries in the United States (Rahim \& Cosby, 2016), the restaurant industry in India (Sharma \& Singh, 2016), in various service companies (airlines, banks, hospitality, retail, etc.) in South Korea (Shin \& Hur, 2019), various business industries in Indonesia (Tricahyadinata et al., 2020), several companies operating in the Jakarta area ( Selamat et al., 2019), and in Gowa (Rocky \& Setiawan, 2018). Based on the description above, the research hypothesis was compiled, as follows:

H2: Workplace incivility has a positive and significant effect on turnover intention of employees of the Ministry of Agriculture's vertical agency in Manokwari.

\section{Job Embeddedness Role as Moderator}

Job Embeddedness can be used to predict turnover intention (Mitchell et al., 2001; Coetzer et al., 2017). Because it has a big role in controlling turnover intention, several studies involve the role of job embeddedness in moderating (weakening) turnover intention behavior as a result of dissatisfaction problems that can reduce the level of welfare felt by employees. Muhammad et al. (2016) reported that life satisfaction is negatively related to employee turnover intention, and job embeddedness is able to moderate the relationship between the two variables. Diener \& Scollon (2003) explain that life satisfaction is one of the main components of individual well-being. If the quality of life of individuals globally increases, then life satisfaction will increase, and perceived wellbeing will also increase.

Workplace well-being has a narrower meaning than life satisfaction. Workplace well-being is more specific for assessing job satisfaction, while life satisfaction includes an assessment of life satisfaction in general. According to Danna \& Griffin (1999), workplace well-being has three dimensions: life/non-work satisfaction, work/job-related satisfaction and general health. This shows that workplace well-being is closely related to satisfaction, so that job embeddedness is able to moderate the relationship between life satisfaction and turnover intention, as the results of research by Muhammad et al. (2016), it is suspected that job embeddedness is also able to moderate the relationship between workplace well-being and turnover intention. Based on the arguments above, the researcher proposes a hypothesis, as follows: 
H3: Job embeddedness plays a role in moderating the influence of workplace well-being on turnover intention in vertical employees of the Ministry of Agriculture in Manokwari.

Job embeddedness can also play a role as a moderator in weakening employee turnover intention as a result of various conflicts that have the potential to cause turnover intention. Aditya \& Handoko (2019) reported that work-family conflict has a positive effect on turnover intentions, and it is known that job embeddedness plays a moderating role in the relationship between work-family conflict and turnover intentions. Another study also found that off-the-job embeddedness was able to weaken turnover intention due to the impact of work-life conflict (Treuren \& Fein, 2018). Because the results of a literature search (via Google Scholar) have not found any research reports that use job embeddedness as a moderating variable in the relationship between workplace incivility and turnover intention, the researchers used work-life conflict and work-family conflict as a reference in formulating hypotheses. This reference is based on the similarity of the nature of work-life conflict, work-family conflict and workplace incivility, which can both cause work stress and turnover intention. Based on the arguments above, the researcher proposes a hypothesis:

H4: Job embeddedness plays a role in moderating the effect of workplace incivility on turnover intention in vertical employees of the Ministry of Agriculture in Manokwari.

\section{Research and Methodology}

The population in this study were all civil servants in the vertical agency of the Ministry of Agriculture in Manokwari, totaling 140 Civil Servants (PNS). All members of the population in this study were used as samples (saturated sample or census method).

Table 1 presents the variables and indicators used in this study. Collecting data using a questionnaire distributed to respondents. The answer choices used a Likert scale, namely: 5 (strongly agree) to 1 (strongly disagree) for the variables TI, WWB, and JE. On unfavorable items, the scale rating is the opposite of the rating rules. While WIC uses a Likert scale, namely: 5 (very often) to 1 (never). Based on the results of distributing questionnaires to 140 civil servants, 121 questionnaires returned and declared eligible for further processing (response rate 86\%). Data analysis using SmartPLS 3.0 with Second Order Confirmatory approach.

Table 1: Variables and indicators

\begin{tabular}{lll}
\hline Variable & Indicator & References \\
\hline Turnover Intention (TI) & $\begin{array}{l}\text { Y1. Thinking of quitting; Y2. Intention to searchfor alternatives; Y3. } \\
\text { Intention to quit }\end{array}$ & Abelson (1987) \\
\hline $\begin{array}{l}\text { Workplace Well-Being } \\
\text { (WWB) }\end{array}$ & X1.1. Core affect; X1.2. Intrinsic value; X1.3. Extrinsic value & Page (2005) \\
\hline Workplace Incivility (WIC) & $\begin{array}{l}\text { X2.1. Gossiping; X2.2. Privacy invasion; X2.3. Exclusionary behavior; } \\
\text { X2.4. Hostility }\end{array}$ & $\begin{array}{l}\text { Cortina et } \\
\text { (2001) }\end{array}$ \\
\hline Job Embeddedness (JE) & Z1. Link organization; Z2. Fit organization; Z3. Sacrifice organzation & Karapete (2013) \\
\hline
\end{tabular}

\section{Analysis and Findings}

\section{Respondents Characteristics}

The majority of respondents were male (61\%), aged between 26 - 45 years $(70 \%)$, had less than 20 years of service (87\%), and had a bachelor's and master's degree (72\%). Based on this data, it can be concluded that the majority of respondents have strong body/health and spirit in carrying out all the work given.

\section{Partial Least Square (PLS) Results Analysis}

\section{Evaluation of the outer model}

The evaluation of the outer model aims to determine the validity and reliability of the measurement instruments used in this study. Evaluation of this stage can be seen from the values of convergent validity, discriminant validity, and composite reliability.

\section{Convergent Validity}

This test can be done by knowing the value of each loading factor. The loading factor value describes the magnitude of the correlation between each measurement item (an indicator on the questionnaire) and the latent variable (construct). An indicator item is said to have met convergent validity if the loading factor value on each path (path) between components (latent variables) and manifest variables is 0.7 (Hartono, 2016).

The results of the validation test show that all indicators in this study are declared statistically valid because they have a loading factor value above 0.7 except X1.3.6, X2.3.2, Y2.2, Y3.1, Y3.2 so they must be excluded from the analysis later in the re-analysis. Figure 1 shows the outer loading research model after all indicators are said to be valid. 


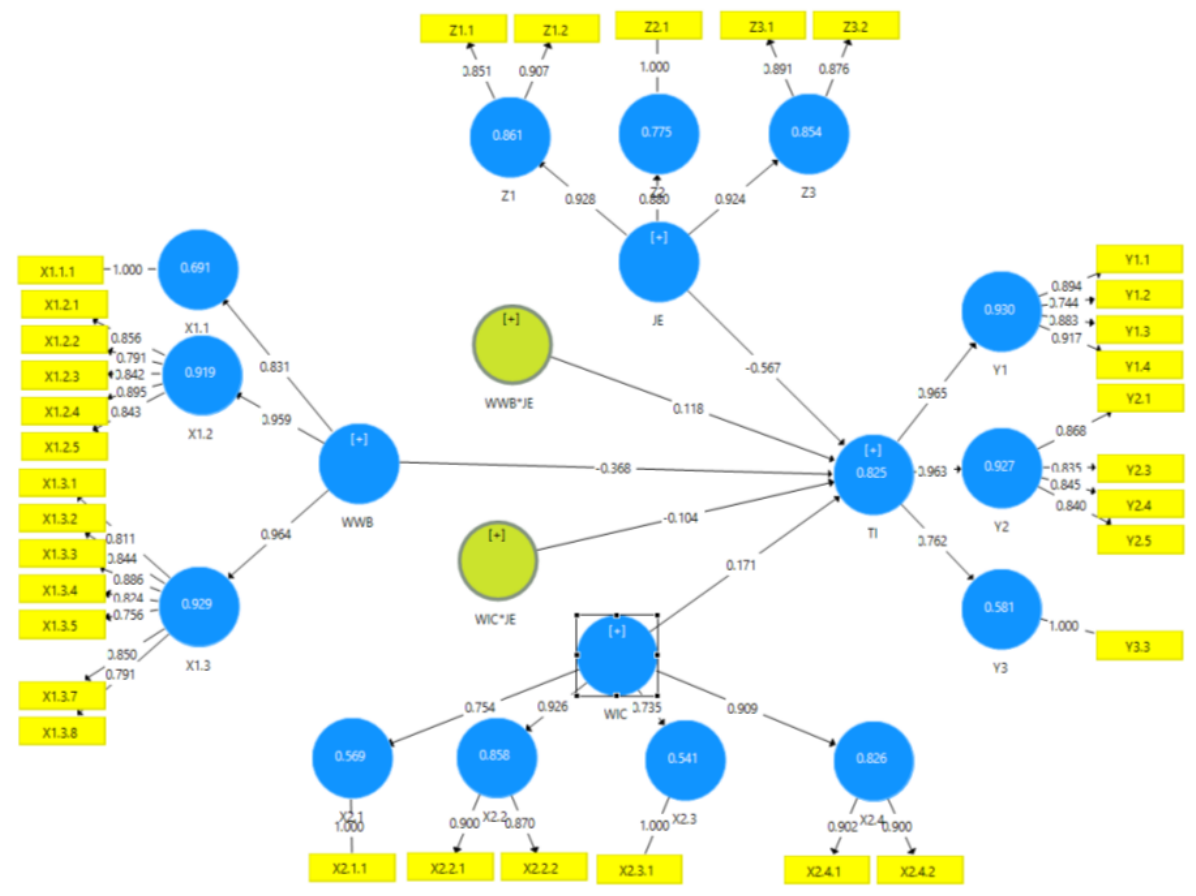

Figure 1: PLS Model Outer Path Diagram

\section{Discriminant Validity}

One other method to determine discriminant validity is by looking at the cross-loading value. An indicator is declared to meet discriminant validity if the value of the cross-loading indicator on the variable is the largest compared to other variables. Table 2 presents the cross-loading value of each indicator in this study. It can be seen that the cross-loading value of each indicator in the variable is higher than the other variables, so that in this study it can be said to have good discriminant validity.

Table 2: Cross Loadings

\begin{tabular}{lllll}
\hline & JE & TI & WIC & WWB \\
\hline X1.1.1 & 0.484 & -0.633 & -0.180 & $\mathbf{0 . 8 3 1}$ \\
X1.2.1 & 0.511 & -0.632 & -0.171 & $\mathbf{0 . 8 2 0}$ \\
X1.2.2 & 0.377 & -0.471 & -0.160 & $\mathbf{0 . 7 1 4}$ \\
X1.2.3 & 0.527 & -0.589 & -0.206 & $\mathbf{0 . 8 1 5}$ \\
X1.2.4 & 0.564 & -0.661 & -0.284 & $\mathbf{0 . 8 6 5}$ \\
X1.2.5 & 0.542 & -0.637 & -0.225 & $\mathbf{0 . 8 3 2}$ \\
X1.3.1 & 0.483 & -0.545 & -0.181 & $\mathbf{0 . 7 9 7}$ \\
X1.3.2 & 0.487 & -0.607 & -0.278 & $\mathbf{0 . 8 4 3}$ \\
X1.3.3 & 0.527 & -0.637 & -0.295 & $\mathbf{0 . 8 3 9}$ \\
X1.3.4 & 0.543 & -0.693 & -0.247 & $\mathbf{0 . 8 0 7}$ \\
X1.3.5 & 0.479 & -0.547 & -0.313 & $\mathbf{0 . 7 2 5}$ \\
X1.3.7 & 0.541 & -0.598 & -0.184 & $\mathbf{0 . 8 1 4}$ \\
X1.3.8 & -0.531 & -0.271 & $\mathbf{0 . 7 2 4}$ \\
X2.1.1 & $-0,113$ & 0.272 & $\mathbf{0 . 7 5 4}$ & -0.279 \\
X2.2.1 & -0.050 & 0.277 & $\mathbf{0 . 8 6 8}$ & -0.236 \\
X2.2.2 & -0.103 & 0.247 & $\mathbf{0 . 7 6 7}$ & -0.251 \\
X2.3.1 & -0.132 & 0.331 & $\mathbf{0 . 7 3 5}$ & -0.237 \\
X2.4.1 & 0.005 & 0.159 & $\mathbf{0 . 8 2 3}$ & -0.168 \\
X2.4.2 & -0.036 & 0.280 & $\mathbf{0 . 8 1 5}$ & -0.192 \\
Y1.1 & -0.682 & $\mathbf{0 . 8 4 8}$ & 0.293 & -0.635 \\
Y1.2 & -0.653 & $\mathbf{0 . 7 2 4}$ & 0.149 & -0.591 \\
Y1.3 & -0.633 & $\mathbf{0 . 8 2 2}$ & 0.279 & -0.583 \\
Y1.4 & -0.728 & $\mathbf{0 . 9 2 0}$ & 0.355 & -0.648 \\
\hline
\end{tabular}




\begin{tabular}{lllll}
\hline Table Cont'd & & & & -0.554 \\
Y2.1 & -0.725 & $\mathbf{0 . 8 3 7}$ & 0.171 & -0.595 \\
Y2.3 & -0.605 & $\mathbf{0 . 7 6 4}$ & 0.222 & -0.626 \\
Y2.4 & -0.577 & $\mathbf{0 . 8 2 9}$ & 0.404 & -0.631 \\
Y2.5 & -0.710 & $\mathbf{0 . 8 2 7}$ & 0.257 & -0.628 \\
Y3.3 & -0.684 & $\mathbf{0 . 7 6 2}$ & 0.261 & 0.262 \\
Z1.1 & $\mathbf{0 . 7 1 9}$ & -0.445 & 0.127 & 0.636 \\
Z1.2 & $\mathbf{0 . 8 9 9}$ & -0.837 & -0.167 & 0.651 \\
Z2.1 & $\mathbf{0 . 8 8 0}$ & -0.696 & -0.207 & 0.534 \\
Z3.1 & $\mathbf{0 . 8 4 0}$ & -0.586 & -0.120 & 0.429 \\
Z3.2 & $\mathbf{0 . 7 9 2}$ & 0.071 & \\
\hline Sour
\end{tabular}

Source: Primary Data (processed), 2021. WWB: Workplace Well-Being, WIC: Workplace Incivility, TI: Turnover Intention, JE : Job Embeddedness.

In addition to observing the cross-loading value, discriminant validity can also be determined by looking at the average variant extracted (AVE) value and the AVE root value and the correlation between latent variables. The AVE value of each indicator is required $>0.5$ for a good model (Hartono, 2016).

Table 3: Average Variant Extracted (AVE)

\begin{tabular}{ll}
\hline Variable & AVE \\
\hline TI & 0,667 \\
WWB & 0,645 \\
WIC & 0,632 \\
JE & 0,686 \\
\hline
\end{tabular}

Source: Primary Data (processed), 2021. TI: Turnover Intention; WWB: Workplace Well-Being; WIC: Workplace Incivility; JE: Job Embeddedness.

Based on Table 3, it can be seen that the AVE value for each variable in the analysis model of this study has a good construct validity value, namely the AVE value $>0.5$, so it is stated that each variable has good discriminant validity.

Table 4: AVE Root Value and Correlation Between Latent Variables

\begin{tabular}{lllll}
\hline & JE & TI & WIC & WWB \\
\hline JE & $\mathbf{0 . 8 2 8}$ & & & \\
TI & $-0,817$ & $\mathbf{- 0 , 8 1 7}$ & & \\
WIC & -0.089 & 0.328 & $\mathbf{0 . 7 9 5}$ & $\mathbf{0 . 8 0 3}$ \\
WWB & 0.623 & -0.748 & -0.285 & \\
\hline
\end{tabular}

Source: Primary Data (processed), 2021. TI: Turnover Intention; WWB: Workplace Well-Being; WIC: Workplace Incivility; JE: Job Embeddedness.

Table 4 shows the AVE root value and the correlation between Latin variables. The number in bold is the root value of the AVE (Average Variance Extracted) of each construct, while the number that is not in bold is the correlation value between the construct and other constructs in the model. The AVE root value looks higher than the correlation between constructs, so it is stated that each variable has good discriminant validity.

\section{Composite Reliability}

The reliability test can be seen from the value of composite reliability and Cronbach's alpha. Composite reliability is the part that is used to test the value of the reliability of indicators on a variable. The reliability test with composite reliability can be strengthened by using the Cronbach alpha value. A variable can be declared reliable if it has a composite reliability value >0.6 (Ghozali, 2018) and has a Cronbach alpha value > 0.7 (Eisingerich \& Rubera, 2010; Hartono, 2016). Table 5 presents the composite reliability and Cronbach alpha values for each variable in this study.

Table 5: Composite Reliability and Cronbach Alpha

\begin{tabular}{lll}
\hline Variable & Composite Reliability & Cronbach Alpha \\
\hline TI & 0,947 & 0,937 \\
WWB & 0,959 & 0,954 \\
WIC & 0,911 & 0,883 \\
JE & 0,916 & 0,886 \\
\hline
\end{tabular}

Source: Primary Data (processed), 2021. TI: Turnover Intention; WWB: Workplace Well-Being; WIC: Workplace Incivility; JE: Job Embeddedness. 
Based on the data in Table 5 above, it is known that the composite reliability value of all research variables is $>0.6$ and the Cronbach alpha value of each research variable is $>0.7$. These results indicate that each variable has met the requirements for composite reliability and Cronbach's alpha values, so it can be concluded that all variables have a high level of reliability.

\section{Inner Model Evaluation}

After the evaluation of the measurement model (outer model) is fulfilled, then the evaluation of the structural model (inner model) is carried out. The inner model shows the relationship between the variables and the value of R2. Structural model testing was conducted to test the hypothesis. Hypothesis testing is done by bootstrap. The results of the PLS bootstrapping output in this research model are shown in Figure 2.

\section{Coefficient of Determination}

The coefficient of determination $\left(\mathrm{R}^{2}\right)$ is a measure of the proportion of variation in the value of the affected variable (endogenous) which can be explained by the influencing variable (exogenous). The value of $\mathrm{R}^{2}$ is useful for predicting whether the model is good or bad (Juliandi, 2018). In this study, the values of $\mathrm{R}^{2}$ and $\mathrm{R}^{2}$ (adjusted) obtained were 0.825 and 0.818 . According to Juliandi (2018) and Ghozali (2018), these values are high, so it can be concluded that the structural model is good (substantial). The interpretation of the $\mathrm{R}^{2}$ value in this study, namely the variability of endogenous variables (turnover intention) can be explained by the exogenous variables in this study (workplace well-being, workplace incivility, job embeddedness, workplace well-being $\mathrm{x}$ job embeddedness interactions, and workplace incivility x job embeddedness interactions) of $81.8 \%$.

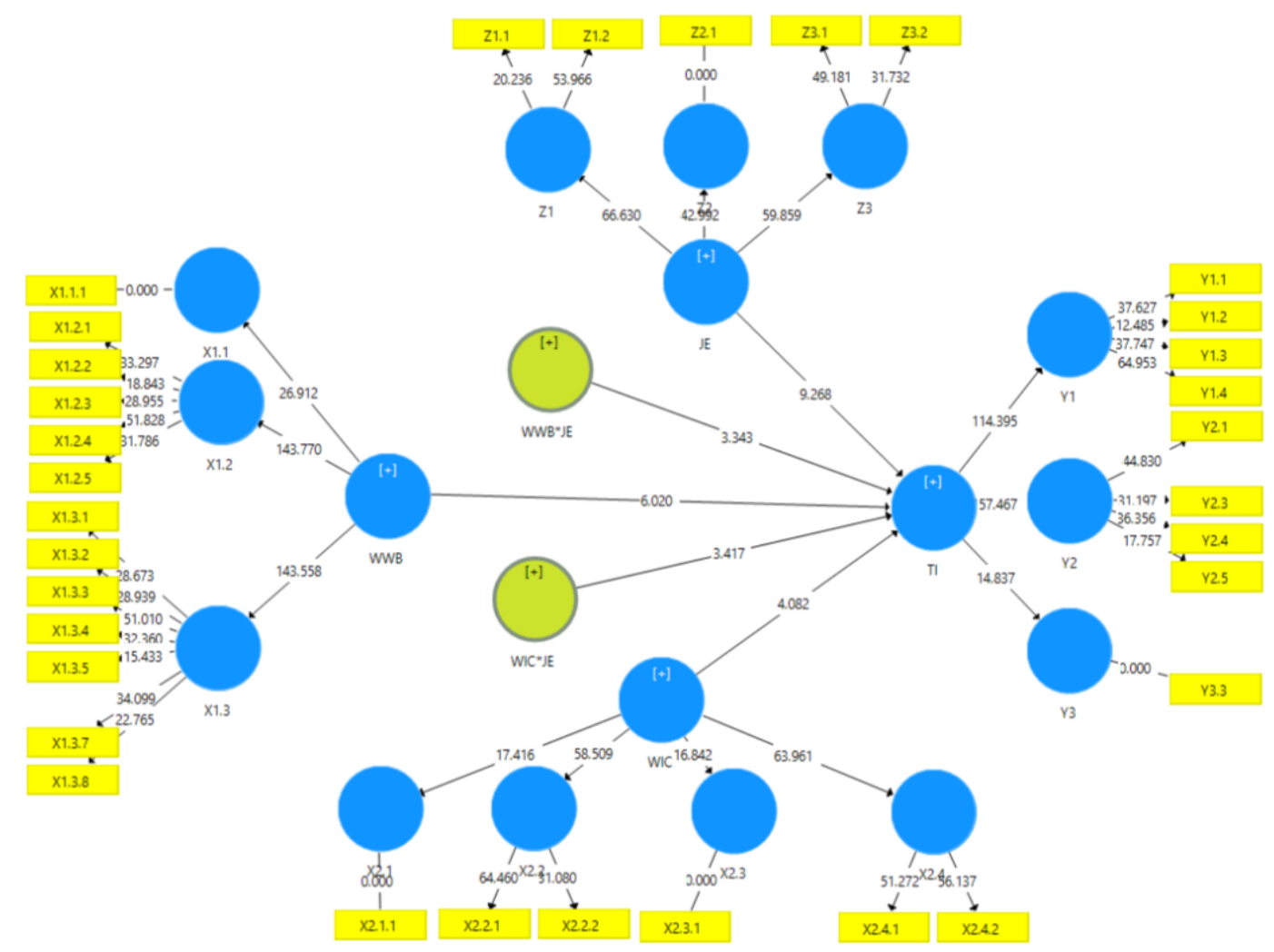

Figure 2: The results of the PLS bootstrapping

\section{Path Coefficient}

The significance of the influence between the constructs can be seen from the path coefficient. The significance value of the path coefficient can be known from the $t$ test (critical ratio) obtained from the bootstrapping process. Table 6 presents the results of path coefficient analysis for testing the hypothesis proposed in this study.

The criteria for the significance of an exogenous variable to an endogenous variable are:

i. If P-Value 0.05 or T Statistics > 1.96, it means that exogenous variables have a significant effect on endogenous variables.

ii. If P-Value $>0.05$ or $\mathrm{T}$ Statistics $<1.96$, it means that the exogenous variable has no significant effect on the endogenous variable. 
Table 6: Path Coefficients

\begin{tabular}{|c|c|c|c|c|c|c|c|}
\hline & Original Sample (O) & $\begin{array}{l}\text { Sample } \\
\text { (M) }\end{array}$ & Mean & $\begin{array}{l}\text { Standard } \\
\text { (STDEV) }\end{array}$ & Deviation & T Statistics (O/STDEV) & P Value \\
\hline WWB -> TI & $-0,368$ & $-0,370$ & & 0,061 & & 6,020 & 0,000 \\
\hline WIC -> TI & 0,171 & 0,172 & & 0,042 & & 4,082 & 0,000 \\
\hline WWB*JE $\quad \rightarrow$ & 0,118 & 0,117 & & 0,035 & & 3,343 & 0,001 \\
\hline $\begin{array}{l}\mathrm{TI} \\
\mathrm{WIC} * \mathrm{JE}->\mathrm{TI}\end{array}$ & $-0,104$ & $-0,105$ & & 0,031 & & 3,417 & 0,001 \\
\hline
\end{tabular}

Source: Primary Data (processed), 2021. TI: Turnover Intention; WWB: Workplace Well-Being; WIC: Workplace Incivility; JE: Job Embeddedness.

Based on Table 6 it is concluded that:
i. WWB has a significant effect $(\mathrm{P}<0.05)$ on TI. Means $\mathrm{H} 1$ is accepted.
ii. WIC has a significant effect $(\mathrm{P}<0.05)$ on TI. Means $\mathrm{H} 2$ is accepted.
iii. WWB*JE has a significant effect $(\mathrm{P}<0.05)$ on TI. Means $\mathrm{H} 3$ is accepted.
iv. WIC*JE has a significant effect $(\mathrm{P}<0.05)$ on TI. Means $\mathrm{H} 4$ is accepted.

\section{Discussion}

\section{Effect of Workplace Well-Being on Turnover Intention}

Based on Table 6, it is known that workplace well-being has a negative and significant $(\mathrm{P}<0.05)$ effect on turnover intention. That is, the lower the level of welfare in the workplace felt by employees of the Ministry of Agriculture's vertical agency in Manokwari, the more the employee's desire to move agencies to work units or other work units within the Ministry of Agriculture of the Republic of Indonesia will increase. or to government agencies outside the Ministry of Agriculture of the Republic of Indonesia, and vice versa. These results indicate that the first hypothesis (H1) of this study is accepted.

The results of this study are the same as reports from previous studies, such as the results of Vani's research (2014) on employees of the ABC \& Partners Public Accounting Firm, Jakarta, which reported that workplace well-being had a negative and significant effect on turnover intention in the office employees. The same result was reported by Maulana (2018) who reported the results of his research on 110 employees of company $\mathrm{X}$ in the city of Malang that workplace well-being had a negative and significant effect on turnover intention. Watoni \& Suyono (2020) also found a negative and significant relationship between workplace well-being and turnover intention in employees of Islamic Rural Banks in Indonesia. Likewise, the Filho \& Claro (2019) report that there is a negative correlation between workplace well-being and turnover intention. Amin \& Akbar (2013) who conducted research on hotel employees in Medan also found a negative relationship between psychological well-being and turnover intentions.

Previous research reports as stated above all support the results of this study, that employee turnover intention behavior in an organization will increase if the employee's perceived workplace well-being decreases. This shows that there is an understanding among researchers regarding the importance of an organization paying attention to aspects of the workplace well-being of its employees so as not to cause turnover intention behavior in its employees.

According to Danna \& Griffin (1999), aspects of workplace well-being that employees of an organization must possess so that employees can work optimally, namely the fulfillment of life satisfaction (non-work satisfaction) which includes satisfaction with social life, family life, recreational pleasures , spiritual condition, as well as other well-being in life outside the work environment; fulfillment of work/job-related satisfaction in the form of employee satisfaction with matters related to work, such as wages, promotion opportunities, working conditions, and co-workers; and the fulfillment of general health in the form of general health, both physical and mental health.

On the other hand, Page (2005) said that there are 13 aspects of workplace well-being that must be met by employees, which are divided into two factors, namely intrinsic and extrinsic factors. Intrinsic factors, including: responsibility at work, the meaning of work, independence in work, use of abilities and knowledge at work, and feelings of achievement at work. Extrinsic factors, namely: time utilization, working conditions, supervision, promotion opportunities, recognition of good performance, rewards as individuals at work, wages, and job security. In addition to these 13 aspects, according to Page (2005), workplace well-being is also strongly influenced by core affect, namely overall job satisfaction related to job satisfaction and work related affect. An institution or organization that ignores the aspects of workplace well-being as described above can cause employees to feel less comfortable at work so that it can lead to turnover intention behavior.

\section{Effect of Workplace Incivility on Turnover Intention}

The results of this study indicate that workplace incivility has a positive and significant effect $(\mathrm{P}<0.05)$ on turnover intention (Table 6). This means that the increased workplace incivility behavior that is felt or experienced by employees of the Ministry of Agriculture's vertical agency in Manokwari, the more the employee's desire to change agencies (turnover intention) to work units or 
other work units within the Ministry of Agriculture of the Republic of Indonesia or to government agencies outside the Ministry of Agriculture of the Republic of Indonesia, and vice versa. These results mean that the hypothesis (H2) in this study is declared accepted.

Previous studies have also found that workplace incivility is positively related to employee turnover intention in various organizations. Research by Rahim \& Cosby (2016) which uses respondents with an average age of $22.65 \pm 6.63$ years and work experience of $2.02 \pm 6.95$ years, comes from various industries in the United States, including manufacturing, services, health, hospitality, and finance, found the same pattern as this study, namely a positive relationship between workplace incivility and turnover intention.

Several other research results also reported the same thing, such as the report by Sharma \& Singh (2016) who conducted research on the restaurant industry in India, they found that workplace incivility was negatively related to job satisfaction, but positively related to turnover intention. Another study also showed that coworker rudeness is closely related to organizational outcomes such as job satisfaction, performance and turnover intention (Rhee et al., 2017).

Research in various service companies (airlines, banks, hotels, retail, etc.) in South Korea, shows similar results to the results of this study that workplace incivility is positively related to turnover intention (Shin \& Hur, 2019). Rocky \& Setiawan (2018) research on employees at CV. Metalik Baru also concluded the same thing that workplace incivility had a positive effect on turnover intention. Congratulations et al. (2019) which conducted a study of 300 employees (52\% male, 83\% aged 21-30 years, 67\% high school education, and 65\% unmarried) from 15 companies operating in the Jakarta area, reported their research results that support the results In this study, workplace incivility has a positive effect on turnover intention.

The results of Tricahyadinata et al. (2020) on employees from various business industries in Indonesia found the same thing as the results of this study that workplace incivility has a positive effect on turnover intentions. The results of the research by Hendryadi \& Zannati (2018) involving 300 respondents (consisting of 52\% women and $48 \%$ men, 56\% aged $<25$ years and $44 \%$ aged $>25$ years, $65 \%$ are unmarried, and $59 \%$ have years of service). $<3$ years) also found that workplace incivility was positively related to turnover intention. Regarding gender, the results of his research conclude that male employees have a higher level of workplace incivility than female employees.

\section{The Role of Job Embeddedness in Moderating Workplace Well-Being and Workplace Incivility Relationships with Turnover Intention}

Table 6 shows that there is a significant interaction effect of workplace well-being and job embeddedness $(\mathrm{P}<0.05)$ on turnover intention (WWB*JE $\rightarrow>$ TI). In Table 6, it is also found that the interaction effect of workplace incivility with job embeddedness significantly $(\mathrm{P}<0.05)$ on turnover intention (WIC*JE -> TI). These results indicate that the third and fourth hypotheses (H3 \& H4) proposed in this study are accepted. It means that job embeddedness is able to play a role in moderating the relationship between workplace well-being and turnover intention and workplace incivility and turnover intention among employees of the Ministry of Agriculture's vertical agency in Manokwari. In another sense, job embeddedness can play a role in weakening turnover intention behavior when there is a problem of dissatisfaction with the low welfare felt by employees at work and the problem of high impoliteness in the workplace experienced by employees of the Ministry of Agriculture vertical agency in Manokwari. Thus, job embeddedness is an important factor to be considered, maintained and improved in order to prevent turnover intention behavior in employees of the Ministry of Agriculture's vertical agency in Manokwari.

Search results regarding reports of previous research results that are directly related to the role of job embeddedness as a moderator of the relationship between workplace well-being and turnover intention, have not been found. However, the role of job embeddedness in weakening (moderating) the high turnover intention behavior due to job dissatisfaction and dissatisfaction in the personal life of employees, has been widely carried out. Muhammad et al. (2016) reported the results of his research on the role of job embeddedness in moderating turnover intention behavior due to the decreased level of well-being of employees as a result of employee dissatisfaction with life. According to the results of his research, life satisfaction has a negative and significant relationship with employee turnover intention, and job embeddedness is able to moderate the relationship between life satisfaction and turnover intention.

In the literature it is explained that life satisfaction is globally defined as an assessment of life in general and specific parts of individual lives, such as satisfaction in the sphere of family, friends, community and satisfaction with oneself (Huebner, 1991). Diener \& Scollon (2003) explain that life satisfaction is one of the main components of well-being. Life satisfaction relates to real experiences of individuals over the life span, such as at school or university, at work and in the family. If the quality of life of individuals globally increases, then life satisfaction will increase, and perceived well-being will also increase.

Workplace well-being has a narrower meaning than life satisfaction. Workplace well-being is more specific for assessing satisfaction at work, while life satisfaction includes an assessment of life satisfaction in general, such as satisfaction within the sphere of family, friends, community, workplace, and self. According to Danna \& Griffin (1999), workplace well-being has three dimensions, namely life/non-work satisfaction, work/job-related satisfaction and general health. This shows that workplace well-being is closely related to satisfaction, so that job embeddedness is able to moderate the relationship between life satisfaction and turnover intention, as the 
results of research by Muhammad et al. (2016), it is suspected that job embeddedness is also able to moderate the relationship between workplace well-being and turnover intention, and this assumption has been proven true from the results of this study.

Reports on the results of previous studies using job embeddedness as a moderating variable in the relationship between workplace incivility and turnover intention have not been found, so researchers use the results of work-life conflict and work-family conflict research as a reference to explain the results found in this study. This reference is based on the similarity of the nature of work-life conflict, work-family conflict and workplace incivility, which can both cause stress and lead to turnover intention behavior. As the results of Aditya \& Handoko's research (2019) which found that work-family conflict has a positive and significant effect on turnover intentions, and it is known that job embeddedness is able to moderate the relationship between work-family conflict and turnover intentions. Another study also found that off-the-job embeddedness was able to weaken the impact of work-life conflict on turnover intention (Treuren \& Fein, 2018). From the description above, there are indications that job embeddedness can also act as a moderator variable to weaken turnover intention behavior when there is a conflict that causes stress to employees. Workplace incivility behavior also causes stress and has the potential to cause turnover intention behavior in employees, but a high sense of job embeddedness in employees can reduce turnover intention behavior. The results of this study have proven this situation to employees of the Ministry of Agriculture's vertical agency in Manokwari.

\section{Conclusion}

In this study, workplace well-being was found to have a negative and significant effect on turnover intention. This means that the higher the welfare felt by employees at work, the lower the employee's desire to change places of work, and vice versa. Among the three indicators (core affect, intrinsic value, and extrinsic value) used to measure the workplace well-being variable, it was found that extrinsic value is the dominant indicator in its contribution to workplace well-being for employees of the Ministry of Agriculture vertical agency in Manokwari. It is suggested, aspects of extrinsic value, namely the use of time (balance of time for work and personal needs), working conditions, supervisor/supervisor assessment, promotion opportunities, recognition of good performance, awards as individuals at work, pay issues, and security at work, it is necessary to pay more attention to the leadership of this vertical agency in order to improve the welfare of its employees and reduce the turnover intention of its employees.

The workplace incivility variable was also found to have a positive and significant effect on turnover intention. That is, the rarer the workplace incivility behavior that is felt or experienced by employees, the lower the employee's desire to change places of work. Workplace incivility in this study was assessed using four indicators: gossiping, privacy invasion, exclusionary behavior, and hostility. Further analysis shows that privacy invasion is the dominant indicator of workplace incivility found in employees of the Ministry of Agriculture's vertical agency in Manokwari. For this reason, it is recommended that privacy invasion, such as dropping/embarrassing employees at work from both superiors and co-workers, and ignoring/not taking seriously the opinions of employees at work, are behaviors that need to be avoided/prevented, because these things contribute to dominant to workplace incivility behavior in employees of this vertical agency. By preventing these negative things, it is hoped that workplace incivility behavior can be reduced, so that turnover intention can be minimized for employees of the Ministry of Agriculture's vertical agency in Manokwari.

Job embeddedness in this study was proven to be able to moderate the relationship between workplace well-being and turnover intention; and it is also proven to be able to moderate the relationship between workplace incivility and turnover intention in employees of this vertical agency. This means that a high level of job embeddedness is able to weaken the desire or intention of employees to switch agencies (turnover intention) when the perceived workplace well-being is low, and when the perceived workplace incivility is high in these vertical agency employees. It is suggested that job embeddedness needs to be considered, maintained and improved for employees of the vertical agency of the Ministry of Agriculture in Manokwari in order to prevent turnover intention behavior in the employees of the vertical agency.

Author Contributions: Conceptualization, N.A.K. \& M.; methodology, N.A.K. \& M.; Data Collection, N.A.K. \& M.; formal analysis, N.A.K. \& M.; writing — original draft preparation, N.A.K. \& M.; writing — review and editing, N.A.K. \& M.. All authors have read and agreed to the published the final version of the manuscript.

Institutional Review Board Statement: Ethical review and approval were waived for this study, due to that the research does not deal with vulnerable groups or sensitive issues.

Data Availability Statement: The data presented in this study are available on request from the corresponding author. The data are not publicly available due to privacy.

Conflicts of Interest: The authors declare no conflict of interest.

\section{References}

Abelson, M.A. (1987). Examination of avoidable and unavoidable turnover. Journal of Anplied Psychology, 72 (3), 382-386.

Aditya, M.W. \& Handoko, T.H. (2019). Analisis Job Embeddedness sebagai Pemoderasi Hubungan Konflik Pekerjaan-Keluarga dengan Intensi Keluar: Studi pada PT. Prima Kelola Sukses (Blok B Tanah Abang). Tesis S2 Manajemen, UGM, Yogyakarta.

Albattat, A.R., \& Som, A.P.M. (2013). Employee dissatisfaction and turnover crises in the Malaysian hospitality industry. International Journal of Business and Management, 8(5):62-71. DOI:10.5539/ijbm.v8n5p62 
Allen, D. G. (2006). Do organizational socialization tactics influence newcomer embeddedness and turnover? Journal of Management, 32(2), 237-256. doi:10.1177/0149206305280103

Amin, Z., \& Akbar, K.P. (2013). Analysis of psychological well-being and turnover intentions of hotel employees: An empirical study. International Journal of Innovation and Applied Studies, 3(3), 662-671.

Ampofo, E. Y., Coetzer, A., Susomrith, P., \& Rermlawan, S. (2017). The job embeddedness-turnover intentions relationship: Evidence from Thailand.

Andersson, L.M., \& Pearson, C.M. (1999). Tit for tat? The spiraling effect of incivility in the workplace. The Academy of Management Review, 24(3), 452-471. DOI:10.2307/259136

Awang A., Amin, A.R., \& Osman, W. (2013). Job behavioral factors and turnover intention: A case study at sime darby property limited. International Journal of Advances in Management and Economics, 2(6), 103-115.

Bakker, A. B., \& Demerouti, E. (2007). The job demands-resources model: State of the art. Journal of Managerial Psychology, 22(3), 309-328. doi:10.1108/ 02683940710733115

Coetzer, A., Inma, C., \& Poisat, P. (2017). The job embeddedness-turnover relationship: effects of organisation size and work group cohesion". Personnel Review, 46(6), 1070-1088. doi:10.1108/pr-12-2015-0312

Cortina, L.M., Kabat-Farr, D., Leskinen, E.A., M. Huerta, M., \& Magley, V.J. (2013). Selective incivility as modern discrimination in organizations: Evidence and Impact. Journal of Management, 39(6), 1579-1605. DOI: 10.1177/0149206311418835

Cortina, L.M., Magley, V.J., Williams, J.H., \& Langhout, R.D. (2001). Incivility in the workplace: Incidence and Impact. Journal of Occupational Health Psychology, 6(1), 64-80. DOI:10.1037/1076-8998.6.1.64

Crossley, C. D., Bennett, R. J., Jex, S. M., \& Burnfield, J. L. (2007). Development of a global measurement of job embeddedness and integration into a traditional model of turnover. Journal of Applied Psychology, 92, 1031-1042.

Danna, K., \& Griffin, R. W. (1999). Health and well-being in the workplace: A review and synthesis of the literature. Journal of Management, 25(3), 357-384. DOI:10.1177/014920639902500305

Diener, E. \& Scollon, S. (2003). Subjective well-being is desireable, but not the summum bonus. Artikel. http://www.tc.umn.edu.

Eisingerich, A.B. \& Rubera, G. (2010). Drivers of brand commitment: A cross national investigation. Journal of International Marketing, 18(2): 27.

Filho, A.P., \& Claro, J.A.C.S. (2019). The impact of well-being at work and psychological capital over the turnover intention: A study of teachers. Revista de Administração Mackenzie, 20(2), 1-27. doi:10.1590/16786971/ eRAMG190064

Gibson, James L., Donnelly Jr, James H., Ivancevich, John M., Konopaske, Robert (2012). Organizationa Behavior, Structure, Processes, Fourteenth Edition (International Edition).1221 Avenue of The Americas, New York, NY 10020: McGraw-Hill.

Ghozali, I. (2018). Aplikasi Analisis Multivariete Dengan Program IBM SPSS 23. (Edisi 8). Cetakan ke VIII. Semarang: Badan Penerbit Universitas Diponegoro.

Glomb, T.M., \& Liao, H. (2003). Interpersonal aggression in work groups: Social influence, reciprocal, and individual effects. Academy of Management Journal, 46(4), 486-496. DOI:10.2307/30040640

Gong, Y., Chow, I.H., \& Ahlstrom, D. (2011). Cultural diversity in China: Dialect, job embeddedness, and turnover. Asia Pacific Journal Management, 28(2), 221-238 DOI 10.1007/s10490-010-9232-6

Halbesleben, J.R.B., \& Wheeler, A.R. (2008). The relative roles of engagement and embeddedness in predicting job performance and intentions to leave. Work \& Stress, 22(3), 242-256. DOI:10.1080/02678370802383962

Harter, J.K., Schmidt, F.L., \& Keyes, C.L. (2002). Well-being in the workplace and its relationship to business outcomes: A review of the Gallup studies. In C.L. Keyes \& J. Haidt (Eds.), Flourishing: The Positive Person and the Good Life (pp. 205-224). Washington D.C.: American Psychological Association. Copyright () American Psychological Association, Washington D.C. All rights reserved.

Hartono, J. 2016. Teori Portofolio dan Analisis Investasi. BPFE Edisi Kesepuluh. Yogyakarta.

Hauge, L.J., Skogstad, A., \& Einarsen, S. (2009). Individual and situational predictors of workplace bullying: Why do perpetrators engage in the bullying of others?. Work \& Stress, 23(4), 349-358. DOI: 10.1080/ 02678370903395568

Hemdi, M.A., \& Nasurdin, A.M. (2006). Predicting turnover intentions of hotel employees: The influence of employee development human resource management practices and trust in organization. Gadjah Mada International Journal of Business, 8(1), 2142. DOI:10.22146/gamaijb.5625

Hendryadi, \& Zannati, R. (2018). Hubungan workplace incivility dan turnover intention: Efek moderasi gender. Inovasi, 14 (2), 123 133. http://journal.feb.unmul.ac.id/ index.php/INOVASI

Holtom, B. C., \& Inderrieden, E. J. (2006). Integrating the unfolding model and job embeddedness model to better understand voluntary turnover. Journal of Managerial Issues, 18(4), 435- 452.

Huebner, E. S. (1991). Correlates of life satisfaction in children. School Psychology Quarterly, 6(2), 103-111.

Hutagalung, I.D.N. \& Wibawa, I.M.A. (2018). Pengaruh keadilan organisasional terhadap komitmen organisasional dan turnover intention karyawan pada PT. Bank Rakyat Indonesia. E-Jurnal Manajemen Unud, 7(1): 221-250. DOI: https://doi.org/10.24843/EJMUNUD.2018.v7.i01.p09 221

Juliandi, A. (2018). Structural Equation Model Based Partial Least Square (SEM-PLS): Menggunakan SmartPLS. Pelatihan SEMPLS, Program Pascasarjana Universitas Batam. 
Karatepe, O. M. (2013). High-performance work practices, work social support and their effects on job embeddedness and turnover intentions. International Journal of Contemporary Hospitality Management, 25(6), 903-921. doi:10.1108/ijchm-06-20120097

Lee, T. W., Mitchell, T. R., Sablynski, C. J., Burton, J. P., \& Holtom, B. C. (2006). The effects of job embeddedness on organizational citizenship, job performance, volitional absences, and voluntary turnover. Academy of Management Journal, 47(5), 711-722. doi:10.2307/20159613

Lev, S., \& Koslowsky, M. (2012). Teacher gender as a moderator of the on-the-job embeddedness-OCB relationship1. Journal of Applied Social Psychology, 42(1), 81-99. doi:10.1111/j.1559-1816.2011.00868.

Maulana, F. (2018). Pengaruh Workplace Well-Being terhadap Intensi Turnover pada Karyawan. Skripsi Fakultas Psikologi, Universitas Muhammadiyah, Malang.

Mitchell, T. R., Holtom, B.C., Lee, T.W., Sablynski, C.J., \& Erez, M. (2001). Why people stay: Using job embeddedness to predict voluntary turnover. Academy of Management Journal, 44(6), 1102-1121. DOI: 10.2307/3069391

Mobley, W.H. (2011). Pergantian Karyawan:Sebab, Akibat dan Pengendaliannya. Alih bahasa : Nurul Imam. Jakarta: PT Pustaka Binaman Pressindo.

Muhammad, R., Wu, W., Zhang, Y., \& Schaub, D. (2016). The role of job embeddedness and trust in the relationship between ife statisfaction and turnover intention: A moderated Mediation Examination. International Conference on Management Science \& Engineering (23rd), Olten, Switzerland, Agustus 18-20, 2016.

Nostra, N.N., 2011. Hubungan antara Job Embeddedness dan Organizational Citizenship Behavior (OCB) Pada Karyawan. Skripsi Fakultas Psikologi, Universitas Sanata Dharma, Yogyakarta. https://repository.usd.ac.id/29124/2/ 079114069_Full\% 5B1\%5D.pdf

Page, K. (2005). Subjective Wellbeing in the Workplace. Thesis. School Of Psychology Faculty Of Health And Behavioral Sciences Deakin University.

Pearson, C.M, Andersson, L.M., \& Porath, C.L. 2000. Assessing and Attacking Workplace Incivility. Organizational Dynamics, 29 (2), $123-137$.

Price, J.L. (1989). The impact of turnover on the organization. Word and Occupations 16(4), 461-473.

Rahim, A., \& Cosby, D. M. (2016). A model of workplace incivility, job burnout, turnover intentions, and job performance. Journal of Management Development, 35(10), 1255-1265. DOI:10.1108/jmd-09-2015-0138

Reich, T.G., \& Hershcovis, M.S. (2015). Observing workplace incivility. Journal of Applied Psychology, 100(1), 203-215. DOI: $10.1037 / \mathrm{a} 0036464$

Reitz, O.E., Anderson, M.A., \& Hill, P.D. (2010). Job embeddedness and nurse retention. Nursing Administration Quarterly, 34(3), 190-200. doi:10.1097/naq.0b013e3181 e702b7

Rhee, S.Y., Hur, W.M., \& Kim, M. (2017). The relationship of coworker incivility to job performance and the moderating role of self-efficacy and compassion at work: The Job Demands-Resources (JD-R) approach. Journal of Business and Psychology, 32(6), 711-726. https://doi.org/10.1007/s10869-016-9469-2

Ridwan (2015). Problematika keragaman kebudayaan dan alternatif pemecahan (Perspektif Sosiologi). Jurnal Madaniyah, 2(9), 254270.

Rocky, \& Setiawan, R. (2018). Pengaruh workplace incivility dan job burnout terhadap turnover intention pada CV. Metalik Baru. Agora, 6(2), 1-6.

Saoula, O., Fareed, M., Hamid, R.A., \& Abualrejal, H.M. (2019). The moderating role of job embeddedness on the effect of organisational justice and organisational learning culture on turnover intention: A conceptual review. Humanities \& Social Sciences Reviews, 7(2), 563-571. DOI:10.18510/hssr.2019.7267

Saoula, O. \& Johari, H. (2016). The mediating effect of organizational citizenship behavioron the relationship between perceived organizational support and turnover intention: Aproposed framework. International Review of Management and Marketing, 6(7S), 345-354.

Saoula, O., Johari, H., \& Fareed, M. (2018). A conceptualization of the role of organisational learning culture and organisational citizenship behaviour in reducing turnover intention. Journal of Business and Retail Management Research (JBRMR), 12(4), 132-140. https://doi.org/10.24052/JBRMR/ V12IS04/ART-13

Selamat, R.S., Hendryadi, \& Tricahyadinata, I. (2019). Workplace incivility, self efficacy, and turnover intention relationship model: Multi-group analysis. RJOAS, 1(85), 358-368. DOI: 10.18551/rjoas.2019-01.44

Sharma, N., \& Singh, V.K. (2016). Effect of workplace incivility on job satisfaction and turnover intentions in India. South Asian Journal of Global Business Research, 5(2), 234-249. DOI:10.1108/SAJGBR-02-2015-0020

Shehawy, Y. M., Elbaz, A., \& Agag, G. M. (2018). Factors affecting employees' job embeddedness in the Egyptian airline industry. Tourism Review. doi:10.1108/tr-03-2018-0036

Shin, Y., \& Hur, W.-M. (2019). When do service employees suffer more from job insecurity? The moderating role of coworker and customer incivility. International Journal of Environmental Research and Public Health, 16(7), 1298. doi:10.3390/ijerph16071298

Suyono, J., Eliyana, A., \& Ratmawati, D. (2020). The nightmare of turnover intention for companies in Indonesia. Opción: Revista de Ciencias Humanas Sociales, (91), 871- 888. 
Takawira, N., Coetzee, M., \& Schreuder, D. (2014). Job embeddedness, work engagement and turnover intention of staff in a higher education institution: An exploratory study. SA Journal of Human Resource Management, 12(1), 524-534. http://dx.doi.org/10.4102/sajhrm.v12i1.524

Tanova, C., \& Holtom, B. C. (2008). Using job embeddedness factors to explain voluntary turnover in four European countries. The International Journal of Human Resource Management, 19(9), 1553-1568. doi:10.1080/ 09585190802294820

Tarraf, R.C. (2012). Taking a closer look at workplace incivility: Dimensionality and source effects. Electronic Thesis and Dissertation Repository. 642. https://ir.lib.uwo.ca/etd/642

Tricahyadinata, I., Hendryadi, Suryani, Saida Zainurossalamia, Z.A., \& Sukisno, S.R. (2020). Workplace incivility, work engagement, and turnover intentions: Multi-group analysis, Cogent Psychology, 7(1), 1743627, DOI: 10.1080/ 23311908.2020.1743627

Torkelson, E., Holm, K., Bäckström, M., \& Schad, E. (2016). Factors contributing to the perpetration of workplace incivility: the importance of organizational aspects and experiencing incivility from others. Work \& Stress, 30(2), 115-131. DOI: 10.1080/02678373.2016.1175524

Treuren, G. J. M., \& Fein, E. C. (2018). Off-the-job embeddedness as a moderator of the relationship between work and life conflict and turnover intention. The International Journal of Human Resource Management, 1-22. doi:10.1080/09585192. 2018.1510847

Vani, E.A. (2014). Pengaruh Employee Engagement dan Workplace Well-Being terhadap Turnover Intention, Studi pada Kantor Akuntan Publik ABC \& Rekan. Skripsi Program Studi Manajemen, Perbanas, Jakarta.

Virani, Y.S.R., \& Kismono, G. (2021). Job Embeddedness as A Moderator of The Influence of Organizational Justice on Turnover Intentions: Evidence from PT Pupuk Sriwidjaja Palembang. Thesis, Repository Universitas Gadjah Mada. https://repository.ugm.ac.id/id/eprint/130590

Watoni, M.B., \& J. Suyono. (2020). Pengaruh kesejahteraan kerja pada turnover intention (Studi pada Bank Perkreditan Rakyat Syariah di Indonesia). Prosiding Seminar Nasional (29 Februari 2020), Fakutas Psikologi, Universitas Mercu Buana Yogyakarta, 87-92.

Yao, X., Lee, T.W., Mitchell, T.R., Burton, J.P., \& Sablynski, C.S. (2004). Job embeddedness: Current research and future directions. In book: Innovative Theory and Empirical Research on Employee Turnover (pp.153-187). Publisher: Information Age Publishing. Editors: R. Griffeth, P. Hom

Publisher's Note: Bussecon International Academy stays neutral with regard to jurisdictional claims in published maps and institutional affiliations.

\section{(c) (8)}

International Journal of Business Ecosystem and Strategy by Bussecon International Academy is licensed under a Creative Commons Attribution 4.0 International License. 